\title{
Analisis Kualitas Bioetanol Dari Kulit Pisang
}

\author{
G.M Saragih ${ }^{\text {* }}$, Hadrah ${ }^{2}$, dan Dilla Tri Maharani ${ }^{3}$ \\ ${ }^{1,2,3}$ Program Studi Teknik Lingkungan, Fakultas Teknik, Universitas Batanghari \\ Jalan Slamet Riyadi, Kota Jambi \\ e-mail: dillatrimaharani2@gmail.com
}

\begin{abstract}
Indonesia is ranked sixth in banana production with total production in 2015 of 7.299.275. the more people who like bananas, the higher the volume of banana peel waste produced. Banana peels are usually thrown away immediately and can contaminate the soil surface because banana peels contain acid so that it can have an impact on evironmental problems. The starch content of banan peels has the potential to be used as a raw material for bioethanol production with the help of the fermentation process. Therefore this research aims to determine the quality of bioethanol which is produced from several types of banana peels. The types of banana peels used are Ambon banana peel, Barangan banana peel and horn banana peel. The method used to manufacture bioethanol form the types of banana peel of ambon, barangan and horn is fermentation using yeast tape or saccharomyses cereviciae. The variables observed in this study were the variety of banana peel types, fermentation time for 6 days and 10 days, and the use of yeast as much as 5 grams. The fermentation results in the form of bioethanol were analyzed using gas chromatography, the best results from this study were obtained on the type of banana peel of Ambon for 10 days, that is $4.451 \%$ bioethanol.
\end{abstract}

Keywords: Bioethanol, banana peels, fermentation

\section{Pendahuluan}

Indonesia merupakan peringkat ke enam dalam produksi pisang dengan total produksi pada tahun 2015 tercatat 7.299.275 ton (BPS, 2017). Indonesia termasuk salah satu negara tropis yang memasok pisang ke Arab Saudi, Singapore dan Jepang. Berdasarkan BPS Provinsi Jambi tahun 2017, Kota Jambi merupakan penghasil produksi pisang sebesar $3.330 \mathrm{kwintal}(\mathrm{kw})$ pertahun yang memiliki jumlah pohon 7.333 buah pertahun. Pohon pisang berpotensi memproduksi (buah pisang) cukup besar karena produksi pisang berlangsung tanpa mengenal musim.

Buah pisang banyak disukai untuk dikonsumsi secara langsung sebagai buah atau diolah menjadi produk konsumsi lain seperti goreng pisang, sale pisang, keripik pisang, getuk, kue dan lain sebagainya. Namun hal ini tidak seimbang dengan pengolahan limbah dari kulit pisang yang sangat banyak jumlahnya. Semakin banyak masyarakat yang mengkonsumsi buah pisang maka volume limbah kulit pisang yang dihasilkan semakin tinggi.

Kulit pisang biasanya langsung dibuang dan dapat mencemari permukaan tanah karena kulit pisang mengandung asam sehingga dapat memberikan dampak terhadap permasalahan lingkungan. Beberapa masyarakat memanfaatkan kulit pisang untuk dijadikan masker wajah namun hanya digunakan dalam jumlah kecil, dengan demikian pemanfaatan limbah kulit pisang masih kurang maksimal. Dewati (2008) melaporkan bahwa limbah kulit pisang dapat dimanfaatkan sebagai bahan pembuatan bioetanol.

Jumlah kulit pisang yang cukup banyak akan memiliki nilai ekonomis yang tinggi jika bisa dimanfaatkan dengan baik. Limbah kulit pisang ambon mengandung monosakarida terutama glukosa sebesar $8,16 \%$, pati $29,37 \%$, pisang barangan mengandung glukosa sebesar $25,8 \%$, pati $28,9 \%$ dan kulit pisang tanduk mengandung glukosa $23,7 \%$ dan pati sebesar 29,60\% sehingga limbah kulit pisang tersebut berpotensi untuk dimanfaatkan sebagai bahan baku dalam pembuatan bioetanol melalui proses fermentasi.

\section{Metode Penelitian}

\subsection{Tempat Penelitian}

Penelitian ini dilakukan di Laboratorium Teknik Lingkungan Universitas Batanghari pada bulan September sampai dengan November 2020

\subsection{Jenis Penelitian}

Jenis penelitian ini menggunakan metode eksperimen. Analisis data menggunakan metode korelasi dan regresi linier sederhana untuk melihat hubungan korelasi/pengaruh antara jenis kulit pisang dan kadar etanol, dimana variabel independen (X) adalah berat sampel jenis kulit pisang, dan untuk variabel dependen (Y) adalah kadar etanol.

\subsection{Alat dan Bahan}

Adapun Peralatan yang digunakan pada penelitian ini yaitu, gelas beaker $1000 \mathrm{ml}, 500 \mathrm{ml}, 250 \mathrm{ml}$, erlemeyer 250 $\mathrm{ml}$, labu ukur $500 \mathrm{ml}$, gelas ukur $100 \mathrm{ml}$, cling wrap, alumunium foil, hot plate stirrer, shaker, desikator, autoclave, cawan porselen, oven, tissue, kapas, gunting, pH Meter, timbangan analitik, corong, kertas saring, pipet tetes, alu. Bahan yang digunakan adalah limbah kulit pisang ambon, limbah kulit pisang barangan, limbah kulit pisang tanduk dan Bahan kimia yang digunakan untuk netralisasi dan hidrolisis asam adalah Padatan $\mathrm{NaOH} 10$ gr dan larutan $\mathrm{H}_{2} \mathrm{SO}_{4} 1 \%$ dan kertas saring Whatman No.14. Bahan yang digunakan untuk fermentasi yaitu Ragi tape.

\subsection{Prosedur Pembuatan Bioetanol}

Proses pembuatan bioetanol dapat dilihat pada gambar 2.1 berikut:

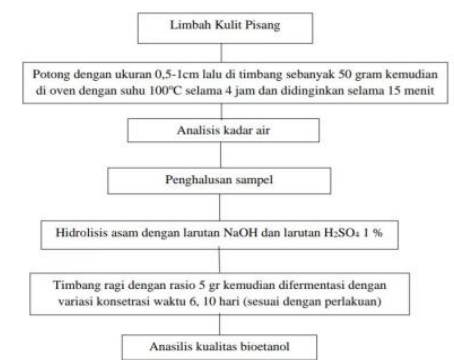

Gambar 2.1 Alur Pembuatan Bioetanol 
1. Tahap awal limbah kulit pisang

Siapkan kulit pisang ambon, pisang barangan, dan pisang tanduk kemudian dipotong-potong menjadi kecil dengan ukuran 0,5-1 cm. Kemudian ditimbang sebanyak $50 \mathrm{gr}$, lalu di oven dengan suhu $100^{\circ} \mathrm{C}$ selama 4 jam. Setelah kering, dikeluarkan dari oven didinginkan selama 15 menit lalu dianalisis kadar air dan kadar patinya.

2. Hidrolisi Pati Kulit Pisang

Menyiapkan larutan untuk menghidrolisis kulit pisang yaitu larutan $\mathrm{NaOH}$ sebanyak $10 \%$ dan larutan $\mathrm{H}_{2} \mathrm{SO} 4$ $1 \%$. Kulit pisang yang telah kering dihaluskan dan dimasukkan ke dalam erlemeyer $250 \mathrm{ml}$ sebanyak 50 gr/sampel untuk 6 sampel. Masukkan larutan $\mathrm{H}_{2} \mathrm{SO} 41 \%$ sebanyak $100 \mathrm{ml}$ ke dalam tiap sampel. Kemudian dioven dengan suhu $50^{\circ} \mathrm{C}$ selama 2 jam, lalu didiamkan selam 1 jam hingga dingin. Lalu dishekker dengan kecepatan 120 rpm selama 10 menit, kemudian ampas diperas dan saring untuk di ambil filtratnya. Filtrat didiamkan selama 24 jam, selanjutnya ditambahkan $\mathrm{NaOH} \quad 10 \%$ sebanyak 15 $\mathrm{ml} /$ sampel, sampai pHnya di angka 5. Semua sampel dipanaskan dan disterilisasi menggunakan autoklaf dengan suhu $121^{\circ} \mathrm{C}$ selama 1 jam, lalu didiamkan hingga dingin selama 15 menit. Proses hidrolisis asam pada penelitian ini dilakukan dengan cara penambahan larutan $\mathrm{H}_{2} \mathrm{SO} 4$ dan dilakukan bertujuan untuk menghilangkan komponenkomponen yang mengikat pati pada kulit pisang. Berdasarkan hal di atas dapat disimpulkan bahwa penambahan $\mathrm{H}_{2} \mathrm{SO} 4$ membantu proses hidrolisis.

3. Fermentasi

Siapkan sampel yang sudah dihidrolisis. Timbang ragi tape sebanyak 5 gr untuk masing-masing sampel. Masukkan ragi tape ke dalam sampel dan ditutup dengan kapas, alumunium foil dan cling warp. Lalu dishekker selama 9 jam dan di fermentasi selama 6 hari untuk 3 sampel dan 10 hari untuk 3 sampel. Tahap fermentasi ini dilakukan variasi konsetrasi ragi tape dan variasi waktu pada proses pembuatan bioetanol. Proses fermentasi ini bertujuan untuk melihat pengaruh waktu dan penambahan jumlah konsentrasi ragi tape terhadap kadar bioetanol yang dihasilkan.

\subsection{Variabel Penelitian}

Variabel penelitian terbagi menjadi 2 (dua) yaitu variabel bebas dan variabel terikat sebagai berikut:

a. Variabel bebas dalam penelitian ini adalah variasi jenis kulit pisang dan waktu fermentasi.

b. Variabel terikat dalam penelitian ini adalah kandungan bioethanol, kadar air dan $\mathrm{pH}$.

\section{Hasil dan Pembahasan}

\subsection{Hasil Kadar Air Pada Sampel Kulit Pisang}

Tabel 3.1 Kandungan Kadar Air Pada Sampel Kulit Pisang

\begin{tabular}{clcc}
\hline No. & Sampel & Berat Sampel (gr) & Kadar Air (\%) \\
\hline 1 & Pisang Ambon 1 & 50 & 60 \\
2 & Pisang Ambon 2 & 50 & 60 \\
3 & Pisang Barangan 1 & 50 & 62 \\
4 & Pisang Barangan 2 & 50 & 61 \\
5 & Pisang Tanduk 1 & 50 & 60 \\
6 & Pisang Tanduk 2 & 50 & 54 \\
\hline
\end{tabular}

\subsection{Hasil Uji Kadar Etanol Pada Kulit Pisang}

Tabel 3.2 Hasil Uji Sampel Bioetanol untuk Parameter Etanol

\begin{tabular}{|c|c|c|c|c|c|c|c|c|}
\hline Nama & $\begin{array}{l}\text { Berat } \\
\text { (mg) }\end{array}$ & & Area & & & Etanol & & \\
\hline $\begin{array}{l}\text { Sampel Kulit } \\
\text { Pisang }\end{array}$ & Sampel & $\mathrm{ACN}$ & Etanol & $\mathrm{ACN}$ & Rasio & $\begin{array}{c}\text { Terukur } \\
\text { (mg) }\end{array}$ & $\begin{array}{c}\text { Terhitung } \\
\text { (mg) }\end{array}$ & $\begin{array}{l}\text { Kadar } \\
(\%)\end{array}$ \\
\hline Pisang Ambon I & 533.8 & 37,7 & 43.587 .77 & $119.346,15$ & 0,365 & 0,567 & 21,364 & 4,002 \\
\hline Pisang Ambon 2 & 525,7 & 48,4 & $41.867,68$ & $134.667,88$ & 0,311 & 0,483 & 23,399 & 4,451 \\
\hline Pisang Barangan 1 & 540,8 & 9,5 & $18.064,80$ & $46.538,77$ & 0,388 & 0,602 & 5,718 & 1,057 \\
\hline Pisang Barangan 2 & 532,8 & 38,3 & $4.693,81$ & $153.359,03$ & 0,031 & 0,054 & 2,066 & 0,388 \\
\hline Pisang Tanduk I & 549,8 & 49.5 & 3.736 .56 & $139.406,54$ & 0,027 & 0,048 & 2,382 & 0.433 \\
\hline Pisang Tanduk 2 & 526.6 & 37.5 & $32.021,99$ & 86.568 .61 & 0,370 & 0,574 & 21.520 & 4,087 \\
\hline
\end{tabular}

Berdasarkan tabel 3.2 dapat dilihat bahwa jumlah etanol tertinggi dihasilkan pada jenis kulit pisang ambon (2) pada hari ke 10 sebesar 4,451\% dan untuk jumlah etanol terendah terdapat pada jenis kulit pisang tanduk (1) dihari ke 6 yaitu sebesar $0,433 \%$. Kualitas bioetanol dapat dipengaruhi oleh kandungan pati dan kadar air pada kulit pisang dan pada saat proses fermentasi.

\subsection{Pengaruh Jenis Kulit Pisang Terhadap Jumlah Etanol yang Dihasilkan}

Jenis pisang yang digunakan pada penelitian ini yaitu pisang ambon, pisang barangan dan pisang tanduk dengan waktu ferementasi selama 6 dan 10 hari. Kemudian dianalisis menggunakan metode korelasi dan regresi linier sederhana.

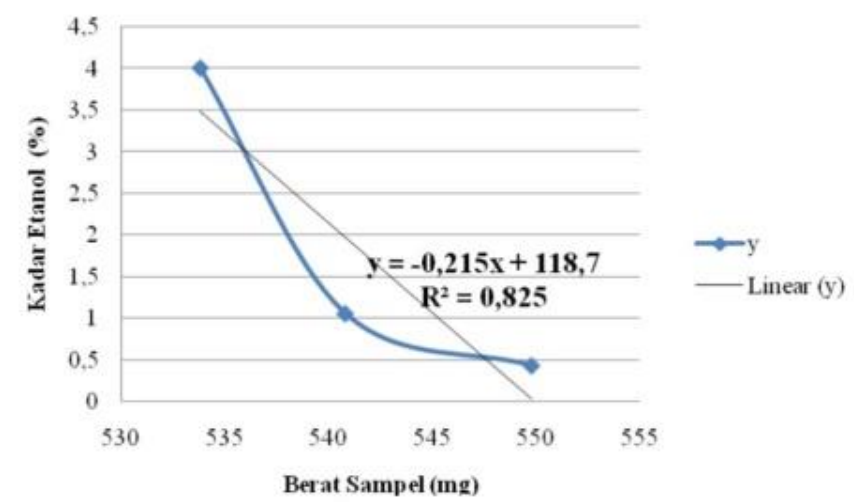

Gambar 3.3 Korelasi Antara Berat Sampel Dengan Kadar Etanol Yang Dihasilkan Melalui Fermentasi 6 Hari

Berdasarkan hasil Gas Chromatography di dapat kadar etanol pada hidrolisat yang sebelumnya dilakukan tahap awal, hidrolisis asam dan fermentasi. Pada gambar 3.3 merupakan hasil analisis data menggunakan korelasi dan regresi linier sederhana yaitu menghasilkan $\mathrm{r}^{2}=0,825$, dimana di dalam korelasi jika $\mathrm{r}^{2}$ menghasilkan -1 atau +1 maka hubungan antar variabel sempurna. Sehingga dapat dinyatakan bahwa hubungan antara berat sampel kulit pisang dengan kadar etanol yang dihasilkan memiliki korelasi linier sempurna untuk fermentasi hari ke-6.

Etanol tertinggi untuk fermentasi 6 hari dihasilkan oleh jenis kulit pisang ambon dengan berat sampel yaitu 533,8 mg yang menghasilkan 4,002\% kadar etanol. Ada beberapa faktor yang dimungkinkan dapat menyebabkan beberapa jenis kulit 
pisang yaitu jenis kulit pisang ambon dan kulit pisang tanduk tersebut menghasilkan kadar etanol yang belum optimum salah satunya waktu fermentasi yang belum mencapai puncaknya sehingga belum menghasilkan kadar etanol yang optimum. Namun untuk jenis kulit pisang barangan untuk fermentasi hari ke-6 ini merupakan hari yang optimum untuk jenis kulit pisang ini.

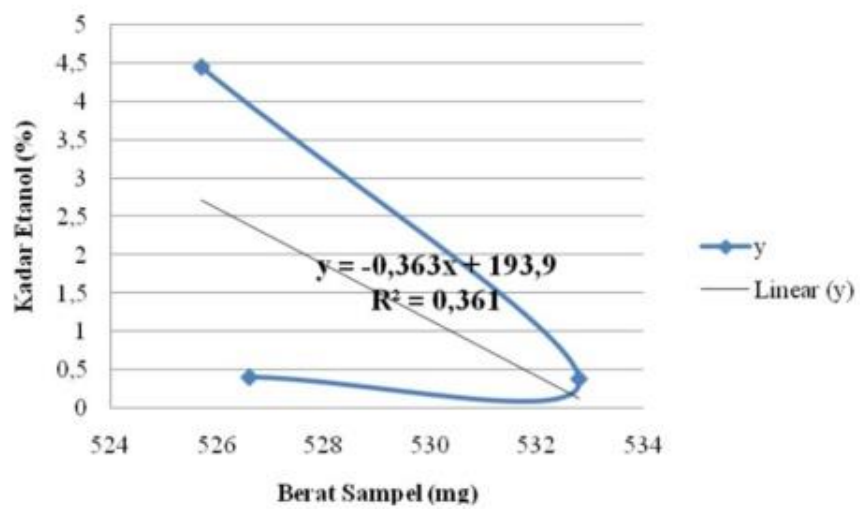

Gambar 3.4 Korelasi Antara Berat Sampel Dengan Kadar Etanol Yang Dihasilkan Melalui Fermentasi 10 Hari

Pada fermentasi hari ke-10 hasil analisis data menggunakan korelasi regresi linier sederhana didapatkan menghasilkan $r^{2}=0,361$. Dengan hasil $r^{2}=0,361$ dapat dinyatakan bahwa hubungan antara berat sampel jenis kulit pisang dengan kadar etanol yang dihasilkan memiliki korelasi linier cukup kuat atau sedang untuk fermentasi hari ke-10 hal ini dikarenakan hasil $\mathrm{r}^{2}$ cenderung lebih kecil dari pada hasil $\mathrm{r}^{2}$ untuk fermentasi hari ke-6. Berdasarkan gambar 4.2 dimana $\mathrm{X}$ adalah berat sampel jenis kulit pisang dan Y merupakan kadar etanol yang dihasilkan oleh fermentasi selama 10 hari, dapat dikatakan bahwa jenis kulit pisang yang menghasilkan kadar etanol tertinggi terdapat pada jenis kulit pisang ambon yaitu sebesar 4,451\% dengan berat sampel sebanyak 525,7 mg.

Ada beberapa faktor yang mempengaruhi kadar etanol yang dihasilkan oleh jenis kulit pisang ini. Salah satunya yaitu tekstur tebal tipis dari kulit pisang itu sendiri.

\subsection{Korelasi Kadar Air dan Kadar Etanol}

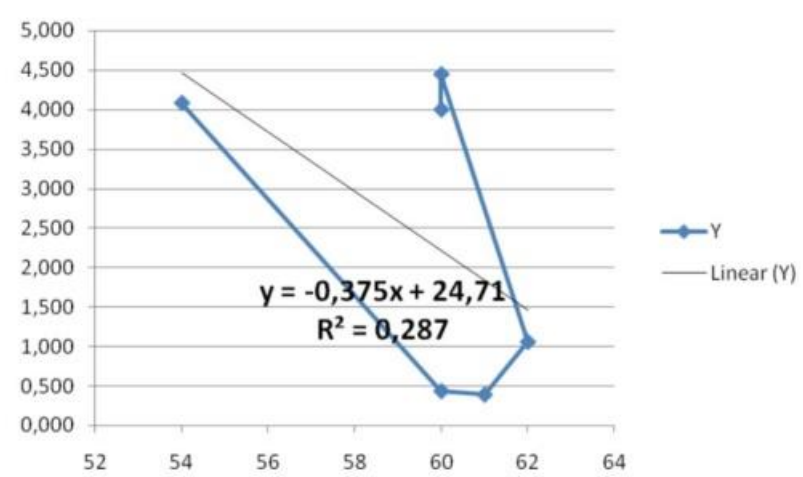

Gambar 3.5 Korelasi Antara Kadar Air dan Kadar Air yang Dihasilkan

Pada gambar 3.5 garis X merupakan hasil kadar air untuk semua jenis sampel kulit pisang yang digunkan untuk fermentasi selama 6 hari dan fermentasi selama 10 hari yaitu sampel kulit pisang ambon, sampel kulit pisang barangan dan sampel kulit pisang tanduk. Kemudian pada garis $\mathrm{Y}$ merupakan hasil kadar etaol untuk fermentasi6 hari dan 10 hari berdasarkan jenis sampel kulit pisang yang digunakan. Dapat dilihat bahwa hubungan korelasi antara kadar air dengan kadar etanol yang dihasilkan, menghasilkan $\mathrm{r}^{2}=0,287$ dimana di dalam korelasi jika $\mathrm{r}^{2}$ menghasilkan - 1 atau +1 maka hubungan antar variabel sempurna. Namun pada analisis korelasi kadar air ini menghasilkan $r^{2}$ relatif rendah. Dengan demikian dapat dikatakan bahwa atau tidak signifikan berpengaruh untuk menghasilkan kadar etanol yang terbaik.

\subsection{Pengaruh Lama Waktu Fermentasi untuk Kualitas Bioetanol}

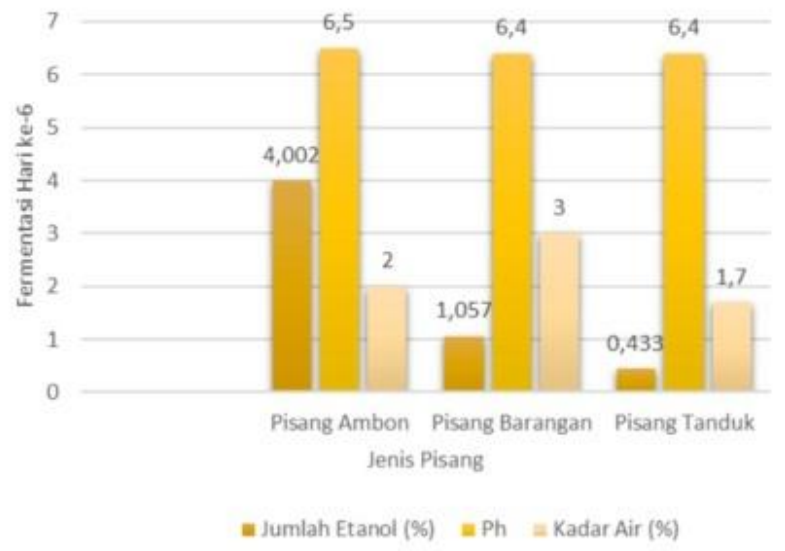

Gambar 3.6 Kualitas Bioetanol Untuk Fermentasi Selama 6 Hari

Berdasarkan gambar 3.6 pada waktu ini menunjukan bahwa pH cenderung lebih standar sesuai dengan SNI- 73902008, dimana standar $\mathrm{pH}$ harus 6,5-9,0 dan untuk standar kadar air berdasarkan SNI-7390-2008 yaitu sebesar 1\%. Pada hari ke-6 pertumbuhan mikroba mulai aktif dan mencapai puncaknya. Sehingga hal ini menunjukan bahwa kadar bioetanol yang dihasilkan pada hari ke-6 waktu fermentasi merupakan waktu yang belum optimal untuk beberapa jenis kulit pisang.

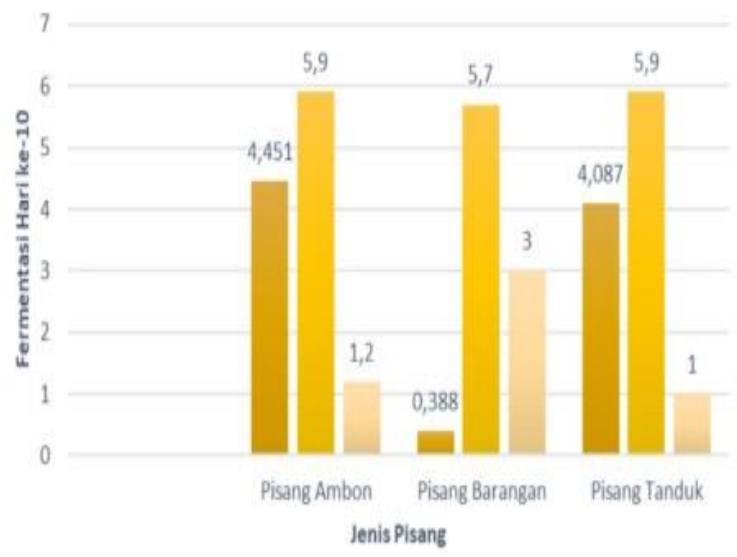

II Jumlah Etanol (\%) $=$ Ph = Kadar Air (\%)

Gambar 3.7 Kualitas Bioetanol Untuk Fermentasi selama 10 hari

Dari hasil uji Gas Chromatography dapat dilihat bahwa 
kadar bioetanol yang paling tinggi pada waktu fermentasi hari ke-10 dengan penggunaan jumlah ragi tape 5 gram adalah pada sampel kulit pisang ambon 4,451\% dan kadar bioetanol paling rendah terjadi pada lama fermentasi hari ke-10 dengan jumlah penggunaan ragi tape 5 gram adalah sampel sebesar $0.388 \%$.

Hal ini menunjukkan bahwa penggunaan jenis kulit pisang memiliki pengaruh terhadap kadar etanol yang dihasilkan, sedangkan untuk waktu fermentasi kadar etanol yang dihasilkan semakin tinggi sampai hari ke-10 untuk jenis kulit pisang ambon dan kulit pisang tanduk. Namun untuk jenis kulit pisang barangan yang memiliki kadar etanol yang dihasilkan semakin menurun pada hari ke-10. Hal ini dikarenakan adanya aktivitas mikroba yang optimal dalam mengubah glukosa menjadi bioetanol dan jumlah kadar air pada sampel juga dapat menentukan hasil etanol yang dihasilkan.

Semakin kecil kandungan kadar air pada sampel maka semakin tinggi kualitas etanol yang dihasilkan namun jika kandungan kadar air tinggi maka semakin kecil pula kualitas etanol yang dihasilkan

\section{Kesimpulan}

1. Kadar bietanol dari variasi jenis kulit pisang yang paling tinggi dihasilkan melalui proses fermentasi selama 10 hari. Yang terdapat pada jenis kulit pisang Ambon dengan penggunaan jumlah ragi tape sebanyak 5 gram yaitu $4,451 \%$ bioetanol. Sedangkan jumlah bioetanol yang yang dihasilkan dari jenis kulit pisang tanduk dengan fermentasi selama 10 hari adalah $4,087 \%$ bioetanol. Pada jenis kulit pisang barangan bioetanol tertinggi dihasilkan melalui proses fermentasi selama 6 hari yaitu sebesar $1,057 \%$ bioetanol.

2. Berdasarkan eksperimen yang dilakukan, lama waktu fermentasi mempengaruhi jumlah bioetanol yang dihasilkan. Waktu optimal untuk proses ferementasi adalah waktu fermentasi hari ke-10 untuk jenis kulit pisang ambon dan kulit pisang tanduk, namun pada jenis kulit pisang barangan waktu yang optimum adalah selama 6 hari.

\section{Ucapan Terima kasih}

Allhamdulillah, Puji syukur Saya panjatkan kepada Allah SWT. Yang telah melimpahkan rahmat dan karunianya, sehingga penyusunan Tugas Akhir dengan judul "Analisi Kualitas Bioetnaol Dari Kulit Pisang “ Penulisan Tugas Akhir ini dilakukan dalam rangka memenuhi salah satu syarat untuk memperoleh gelar Sarjana Teknik Lingkungan pada FakultasTeknik Universitas Batanghari.

\section{Daftar Pustaka}

Adji, Bayu Rahman,(2009), Cabang-cabang Biologi, tersedia: http://princeikki.wordpress.com/2009/07/25/252/,

Badan Pusat Statistik. (2017, Juni 06). Badan Pusat Statistik Tabel Dinamis. Diambil kembali dari Badan Pusat Statistik: https://www.bps.go.id/site/resultTab

Badan Pusat Statistik Provinsi Jambi. (2017). Badan Pusat Statistik Tabel Dinamis. Banks W dan Greenwood CT. 1975. Starch and Its Components. Helsted Press, John

Willey and Sons, New York.

Hambali, et al. 2007. Jarak Pagar Tanaman Penghasil
Biodiesel. Penebar Swadaya: Jakarta.

Harlis . 2015. Pemanfaatan Acetobacter xylinum terhadap Peningkatan Kualitas Nata.Universitas Jambi. Biospecies Journal. 8(1): 29- 33.

Hart, Harold, Leslie E Crame. David J. Hart. 1990. Kimia Organik. Terjemahan Seminar Setiadi Achmadi. Jakarta : Erlangga.

Hidayat, dkk. (2006). Mikrobiologi Industri. Yogyakarta: C.V Andi Offset. Hoffbrand AV, Moss PAH, Pettit JE. 2006. Essential Haematology. Ed ke-5.

Massachusetts: Blackwell Science.

Kusnadi, A.S. dan Yusuf, H.A.S. 2009. Pemanfaatan Sampah Organik Sebagai Bahan Baku Produksi Bioetanol Sebagai Energi Alternatif. Laporan Penelitian Strategis Nasional Tahun Anggaran 2009 (Energi Terbarukan). Bandung: Jurusan Biologi Fakultas Pendidikan Matematika dan Ilmu Pengetahuan Alam Universitas Pendidikan Indonesia.

Liu, Z. \& J.H., Han, 2005, "Film Forming Characteristics of Starches", J. Food Science, Vol. 70, No. 1, E31- E36.

Munadjim, 1982. Teknologi Pengolahan Pisang. Masa Baru. Bandung.

Mudjajanto, Eddy Setyo dan Yulianti, Lilik Noor. 2009. Membuat Aneka Roti.

Jakarta: Penebar Swadaya.

Supriyadi, Ahmad dan Suyanti Satuhu. 2008. Pisang, Budidaya, Pengolahan dan Prospek Pasar. Jakarta: Penebar Swadaya.

Susanti, Lina. 2006. Perbedaan Penggunaan Jenis Kulit Pisang Terhadap Kualitas Nata Dengan Membandingkan Kulit Pisang Raja Nangka, Ambon Kuning Dan Kepok Putih Sebagai Bahan Baku. Tugas Akhir. Semarang: UNNES.

Rikana, Heppy dan Risky Adam, 2008, “Pembuatan Bioetanol dari Singkong Secara Fermentasi Menggunakan Ragi Tape", UNDIP Digital Library, Indonesia, Hal.2-4.

Wijaya, C.H Noryawati M. 2013. Bahan Tambahan Pangan Pewarna. Bogor: IPB 